\title{
The Pattern of Anti-Radicalism Education at Majelis Taklim in Kota Palu
}

\author{
Syamsuri Syamsuri ${ }^{1}$, Nurwahida Alimuddin ${ }^{2}$ \\ \{syamsuri.akil@gmail.com ${ }^{1}$, Nurwahidaalimuddin@gmail.com ${ }^{2}$ \} \\ IAIN Palu, Indonesia ${ }^{1}$, IAIN Palu, Indonesia ${ }^{2}$
}

\begin{abstract}
The pattern of anti-radicalism Education at majelis taklim in Kota Palu is needsbased learning. The formulation of a systematic and coherent curriculum can be accessed through social media belonging to the majelis taklim group of participants. The phenomenological approach to the learning system of majelis taklim in Kota Palu was carried out to observe political, ideological, and cultural influences. The things that appear in the discussion of the participants in majelis taklim are like icebergs. The root of the problem in society is multi-dimensional and crucial but often melts away, due to the charismatic role of community leaders. Alkhairaat and Muhammadiyah community organizations became the protectors of the ideology of majelis taklim in Kota Palu.
\end{abstract}

Keyword : ideology, movement, and community

\section{Introduction}

Kota Palu is the capital of Provinsi Sulawesi Tengah, which has received refugees due to social unrest from Poso Regency, in 2000-2005. As a result of the rioting, there were also several killings and bomb explosions in Kota Palu, because the perpetrators targeted in several locations. The government and community leaders continued to monitor the concern of an escalation of violence in the name of religion, so that the Kota Palu succeeded in preventing radicalism from occurring.

Radicalism is an extreme political or social or religious view that is inconsistent with or contrary to the political, social and religious views recognized in the Unitary State of the Republic of Indonesia which can lead to social, political and inter-religious conflicts or within the same religion. This causing restlessness, peace or disturbing order in community life. In this regard, radicalism needs serious attention by all parties in order to get treatment as early as possible. This early treatment needs to be done so that radicalism does not roll wildly which causes terrorist acts to emerge.

The phenomenon of violence in the name of religion, which is often known as religious radicalism, has become increasingly visible, which ultimately becomes the background for the terrorism movement that has always overshadowed and is a problem currently faced by countries in the world, including Indonesia. Such understanding is not actually caused by a single independent factor. Social, economic, environmental, political and even educational factors also contributed to influencing religious radicalism. However, religious radicalism is often driven by a narrow religious understanding, feelings of pressure, hegemony, psychosocial insecurity, and local and global injustices. This movement gained a large following among the younger generation of Muslims who grew up under a secular-nationalist government system [1].

If we want to look at religious phenomena in the Islamic world globally and in a state such as in Indonesia, the last few years there has been a tendency for some Muslims both globally and in Indonesia to show "Islamic authenticity" (which according to them) is in accordance with the blue print, taught by the Prophet Muhammad. The central issues they raise are around the need to establish a Khilafah Islamiyah (Islamic State) and the formalization of sharia in the life of the nation and state [2].

Referring to the results of survey research conducted by the Jakarta Institute for Islamic Studies and Peace (LaKIP) in 2010, it can be seen that $48.9 \%$ of student data in the Jabodetabek area have loudly stated their approval of radical action. The results of this survey not only stunned the teachers, but what most needed to be a reflection were parents, especially mothers who became 
the first and foremost educators of their children. At this level, it must be fully aware that there is a danger that is threatening children. It should be understood that the emergence of an attitude of approval or acceptance of a value, whether good or bad, is the initial stage of the five stages of a person's affective or attitude in the view of David R. Krathwohl. The five stages of this attitude are receiving, rresponding, valuing, oorganizing, and ccharacterization by a value or value complex [3].

This means, if the children's consent to radical acts is allowed, it may result in them having violent personalities as a way to achieve goals. As a result, radicalism has at least received support even though it is only at the level of children's thinking. So, you can imagine if all the children had the same thoughts, then radicalism would be a "something" that was okay in their eyes.

The data shows cases of religious radicalism targeting young people who are still students. As happened in early 2011, there were three terrorists suspects arrested who were still students at a school in Klaten [4]. It is of a vital importance for this line of research to bring all these scholarships together to figure out what we know so far about the phenomenon of Islamic fundamentalism and extremism. Research on "Islamic Radicalism" and its causes and consequences has become more popular among scholars in several social science disciplines, especially sociologist and political scientists [5].

Incidents like this are an example of how dangerous radicalism is to equalize religion which is increasingly prevalent and combing Muslim youths who are still students and in fact still children. They should be protected and educated to become the next generation of the true nation and religion.

\section{Literature Review}

The emergence of this problematic religious movement often causes public unrest, resulting in the emergence of conflict accompanied by violence Wiwitan [6]. This study suggests that religious movements can trigger radicalism in society. Our research observes religious extension workers who are able to suppress radicalism in Kota Palu.

Islamic resurgence or the phenomenon of escalating religiosity and consciousness seems like scandalous behavioral and practical manifestations of a ,return "e to medieval belief and morality [7]. The phenomenon of religious movements, on the one hand, can increase faith in God. But when religious movements enter the area of interest, the potential for conflict often occurs. The pattern of education carried out by religious educators in Palu City seems to be harmonizing with the community, so that there are efforts to reduce it.

\section{Methods}

This study used a phenomenology of Islamic education for society, many influence of ideology at dakwah content. The phenomenon of violence in the name of religion, which is often known as religious radicalism, has become increasingly visible, which ultimately becomes the background for the terrorism movement that has always overshadowed and is a problem currently faced by countries in the world, including Indonesia

\section{Result and Discussion}

\subsection{Preventing the Potential of Radicalism}

Although there is no data on the perpetrators of radicalism in Kota Palu, it is possible that radicalism will also develop in this area. Especially if there does no effort to prevent the penetration of this understand from the start? It is at this point that the role of the ministry of religion extension workers is required to be more proactive in providing guidance and counseling 
to families in Kota Palu. The targets that were most effective in providing guidance were mothers who were members of the majelis taklim.

Housewives have a very central role in nurturing and guiding their children so they don't fall into radicalism. It's just that, the level of knowledge and understanding of mothers, they still need guidance so that they also have knowledge about things in fostering their children. This knowledge is important so that mothers can direct their children so they do not get involved in radicalism.

Responding to this, the Ministry of Religion Affairs (MORA) of Kota Palu, provides continuous guidance to the community or religious groups. Based on observations, the coaching efforts carried out by the Ministry of Religion of Palu City were given to religious instructors, especially those in the ministry's line of command. This means that guidance against radicalism in the community, especially in religious groups, is left to the extension agents. It is these extension workers who are likely to be at the forefront in providing guidance in order to ward off radicalism. In line with this, one of the extension agents stated that for the effectiveness and efficiency of congregation development, especially women, it is necessary for them to be gathered in one forum. The best and most commonly used container is majelis taklim.

Therefore, since 2016 we have formed Majelis Taklim Sahabat. In this assembly, it examines radicalism so that mothers are not exposed to radicalism. That's why mothers are given a correct and correct understanding of religious knowledge. Talking about radicalism is talking about the doctrine they have in mind. If this doctrine is understood incorrectly by mothers, they will be exposed to radicalism. The danger is that mothers are the ones who are most responsible for the education of their children, especially in the household, so that if this is allowed to do so, their generation may become involved with the radicalism movement. At least there will be abandonment of radicalism in their children.

Therefore, I try to pattern the guidance of the majelis taklim congregation by: First: religious material must be taken from the sanad that reaches the Messenger of Allah, Second: teach alwasatiah (moderate in nature). Then it is very emphasized on mothers so that their children are not exposed to this radicalism. Mothers are taught religious knowledge in order to understand. Especially now that information on radicalism is so massive in cyberspace. Sometimes they learn from the internet. Based on the results of an interview with Fikri, he was an Islamic Religion Officer at the Ministry of Religious Affairs in Palu City, which was conducted on September 26, 2019, "Reading books is done alone without asking the teacher who knows better."

A similar sentiment was also conveyed by one of the extension agents who said that for the past 3 years we extension officers have continued to intensify our training in taklim assemblies in the hope of warding off radicalism. Based on the results of an interview with Marwan Feri, he was once an Islamic Religious Officer at the Ministry of Religious Affairs in Palu City, which was conducted on September 26, 2019, "At least radical views need to be cleaned up as early as possible, especially for mothers because they are the ones who are in direct contact with their children's education."

This statement illustrates that the Islamic religious extension workers in Kota Palu always provide guidance to members of the taklim assembly. In fact, their efforts to pioneer a new taklim council to serve as a forum for gathering congregations, especially mothers, to be given guidance. The frequency of coaching given is adjusted to the schedule in each majelis taklim. This is due to the majelis taklim which have set their own schedules. In line with this condition, Muhammad Idham, Penyuluh Agama Islam MORA in Kota Palu stated that we are Islamic religious extension workers in providing guidance to majelis taklim according to the schedule of events that have been prepared by the taklim assembly itself.

There is a majelis taklim that schedule coaching eight times a month. In the eight times of coaching, four meetings were given lecture materials on radicalism to majelis taklim women with the core material directed at strengthening about radicalism which is a dangerous thing and we must fight together with community leaders, government and religious leaders. Based on the results of an interview with Muhamad Idham, he was once an Islamic Religious Officer at the Ministry of Religious Affairs in Palu City, which was conducted on September 26, 2019, "There is also the taklim council to schedule it every week, every two weeks and once a month. This schedule is adjusted by us as extension agents." 
Penyuluh Agama Islam always adjust to the schedule. It's just that, if there is a situation that is unusual and requires sharpening or preventive action against radicalism, the extension worker asks for time to provide guidance to majelis taklim in their area. Based on the results of an interview with Muhamad Feri, who was once an Islamic Religious Officer at the Ministry of Religious Affairs in Palu City, which was held on September 26, 2019, "This was stated by the Islamic religious instructor who said that in providing counseling to the Majelis Taklim in Kota Palu, we extension officers also adjusted to the situation and conditions. If there are indications / symptoms of radicalism in that place, then we will take immediate action to be followed up."

This statement illustrates that although majelis taklim have set a coaching schedule, but the extension workers think there are things "urgent" to convey to the community immediately, the taklim majelis gather to gather and open recitation events. So, the chain of guidance to majelis taklim was cut off in the current situation, especially those not related to radicalism.

Majelis Taklim in Kota Palu has not difficulty in accessing Islamic religious extension workers to fill every event they conduct. This is monitored by researchers at majelis taklim never empty in any recitation schedule that they have determined. Religious instructors always come to provide guidance, especially those from the ministry of religion. This is also in line with the statement of the religious instructor who stated that based on the Head of the Office of the Ministry of Religion, Palu City, all extension personnel should be proactive in providing guidance. Islamic religious educators in the ranks of the Ministry of Religious Affairs in Palu City always respond to every request and invitation to provide guidance. The point is, wherever we are needed, we will respond.

This statement illustrates that the continuity of guidance to majelis taklim carried out by religious extension workers of the MORA of Kota Palu has always been going well. Not only are that, in coaching the taklim assemblies there patterns. It can be seen that coaching has been carried out by coaching mistakes that rely on the old, namely "the time comes to sense". The extension workers make such preparations so that the coaching program can run well and smoothly.

This was confirmed based on the results of an interview with Agusman, he was an Islamic Religion Officer at the Ministry of Religious Affairs in Palu City. He stated that the coaching program that we always do is not arbitrary, in the sense that it only meets the schedule, but we do with full preparation. At least before we go down to the majelis taklim we will identify the needs of the majelis taklim and especially the identification of radicalism around the majelis taklim environment.

This statement can be understood about the planned effort for an extension worker to provide guidance to the majelis taklim congregation, so that what they convey can be in accordance with the expectations of the majelis taklim congregation. Not only that, extension workers make every effort to do early detection of majelis taklim and the surrounding environment in relation to the existence of radicalism that needs to be overcome.

Penyuluh Agama Islam always pay attention to the conditions of the majelis taklim congregation they cultivate. This is due to the awareness of the religious extension agents of the feeling of boredom and boredom in doing Muslim assemblies. Therefore, one of the Islamic religious extension agents responded to this by always coordinating with the leaders of the majelis taklim to find a solution. This was stated by one of the Islamic religious educators who said that I always tried to make the members of the Taklim Council not feel bored to follow the coaching on every predetermined schedule. Based on the results of an interview with Nikma, he was an Islamic Religion Officer at the Ministry of Religious Affairs in Palu City. She stated that the effort that I did was coordinating with the committee of the taklim assembly, I even went to all the heads of the taklim assembly to exchange ideas about what the members of the women wanted so that they didn't get bored of the taklim assembly. Moreover, only with this taklim assembly, we extension agents can provide effective and efficient guidance to mothers. The same thing was stated by one of the extension agents, who said that,

In order to avoid feeling saturated in the material, the overlapping of the material between one extension and another was also a concern of the extension workers. On this basis, we provide recitation or guidance to the majelis taklim congregation using a material curriculum that has been compiled for the next one year, so that the material is conveyed 
coherently. This is done so that the congregation does not feel bored with the material they receive.

So, the guidance given by the extension personnel to the majelis taklim congregation has been patterned, so that the congregation can receive the material coherently and continuously. Of course, the materials that have been set forth in the curriculum support one another to provide an understanding of the kaffah religion of Islam. With this kaffah understanding of Islam, Muslims will be free from radical understandings.

Not only that, the researchers's observations also found that there was guidance carried out by Islamic religious extension workers who prioritized dialogical of dakwah. At this level, the researcher saw that the extension workers opened up space for the majelis taklim congregation to have a dialogue and issue all their complaints regarding the material being conveyed to the actual problems they were facing at that time. The Islamic Religion Officer of the Ministry of Religious Affairs in Palu City stated that,

This was also emphasized by religious extension workers who said that the preaching pattern, which had been centered only on ustad, was changed by preaching that emphasized the activeness of the congregation. The reason is, in addition to one-way dakwah it can cause boredom and stiffness, also because what is faced is a member of the taklim assembly. Therefore, the method of conveying is used to provide material exposure; the rest is used for dialogue.

The training carried out by the religious extension workers has adopted a better method than the previous method. The training method referred to is a monological method moving to a dialogical method. This method is understood to be a more effective method for guiding the congregation, especially the majelis taklim congregation. The technical implementation is by explaining the material and then opening a question and answer room as wide as possible for the congregation to ask questions related to the material. Even more than that, the extension workers still respond

In providing guidance to majelis taklim, religious extension workers provide material explanations not only in the form of lectures. However, sometimes extension workers provide guidance using technology-based media. The researchers' observations found the use of media in providing guidance, such as in focus. The religious extension agents present material through an in focus with a varied and attractive appearance. Especially if the material directly in contact with radicalism is up to date, the extension workers will play radicalism film footage; from the concept to the latent danger of radicalism. The Islamic Religion Officer of the Ministry of Religious Affairs in Palu City stated that,

The use of audio-visual media in providing guidance to the taklim assembly congregation was also strengthened by the statement of the religious counselor who said that radicalism was something we were always up to date, so we also tried to provide understanding in a more effective way. The way we take it is by using the in focus media. We use this media because it can provide clarity, both sound and image or film. In other words, in focus provides an audiovisual effect, so that the congregation can hear and see firsthand how radicalism really is.

The media used by religious extension agents in providing guidance to the majelis taklim congregation is one medium that is quite effective. This is based on the arrangement of researchers who find their enthusiasm in watching the audiovisual broadcasts of the media. Through this audiovisual effect, the congregation is not only interested in following the material, but also sees first-hand the real issues of radicalism. The enthusiasm of the congregation can be seen from their resilience to sit in the assembly watching the songs and enjoying them casually, but still paying close attention and listening to what is presented in films with the theme of radicalism.

Apart from the media previously mentioned, the extension workers also applied other media. In the researcher's observation, the media apart from visual audiences, extension agents also used online media in the form of the What Sapp application. The religious educators provide their contact numbers to call and share with one another. Even through this online media application, the extension agent creates a what Sapp group with each taklim group that they coach to facilitate communication. Through this online communication, the extension workers opened a space for the majelis taklim congregation to ask and answer questions with the extension agents, especially 
those related to religious issues. The Islamic Religion Officer of the Ministry of Religious Affairs in Palu City stated that,

The use of online media was emphasized by the extension agent, who stated that to improve the relationship between us extension agents and members of the Taklim Majlis in Kota Palu, we created a Whatshap group. Through this online group media, we are able to build an intensive communication network, so that it is not just connecting to silahturrahmi via cyberspace, but more than that. We can exchange ideas, ask questions about religion, and even remind each other about the vigilance of radicalism. Through online media we can also control each other of the assembly against all the possibilities that occur.

The extension's view can provide an overview of the guidance carried out in the taklim assembly in Kota Palu which does not only rely on the old pattern, namely public lectures, but has also made use of information technology. Even by utilizing this technology, extension workers can easily control, remind and be able to ask and answer questions to the members of the majelis taklim they coach. Thus, the guidance for majelis taklim members continues, even though they have not entered the recitation schedule and the like.

Based on the exposure of the research findings in the field, it can be understood that the Islamic religious extension workers in Palu City have been patterned to ward off radicalism, especially for housewives. The pattern that was applied had an effect on the development movement that was getting tidier, systematic, and controlled so that in the end the majelis taklim congregation was not seized by a feeling of boredom and boredom to follow the coaching given by the Islamic religious extension workers in Kota Palu.

The pattern of guidance as described can be seen in several forms. First, the establishment of a roadmap for the majelis taklim area. Through this mapping, extension workers have a reference to provide clear guidance to majelis taklim. Second, with this roadmap, extension workers can easily map the needs of majelis taklim, so they can respond quickly to changes that occur. Third, the pattern of guidance is based on the needs of majelis taklim. This means that the extension workers do not voluntarily fill the event at the taklim council they foster to avoid feeling bored by the members. Fourth, coaching uses a curriculum, so that the material can be well systemized. Fifth, the guidance carried out in majelis taklim has been based on the latest technology media.

\subsection{The Education Pattern of Majelis Taklim in Kota Palu}

The guidance of majelis taklim carried out by Penyuluh Agama Islam in Kota Palu in preventing radicalism has good prospects. This is based on data from the findings of researchers, that there are several things that really support the smooth implementation of the guidance of majelis taklim, namely:

\subsubsection{Activity of extension workers}

The researchers' observations found the attitude of the extension workers in fostering majelis taklim. Each recitation schedule that has been determined by the taklim council, is always filled in by the ministry of religion extension. In fact, extension workers often fill out the schedule because they think there are things that need to be conveyed quickly. This was also stated by one of the extension workers who said that we were extension officers in addition to the instructions from the leadership to respond to the guidance of all majelis taklim, also because of a call from the heart to broadcast the true religion of Islam. Moreover, with the rise of radical ideas which we consider to be contrary to the Islamic religion, which in fact are increasingly tapping our conscience to straighten them out.

This statement emphasized the progressive attitude of the extension workers to provide guidance to the taklim council in order to fight against radicalism. Moreover, the notion of radicalism that cannot be overcome can lead to acts of terrorism. And, the people who are affected by radicalism are not only in the older generation, but also targeting teenagers.

\subsubsection{Extension specifications for dealing with radicalism}

MORA of Kota Palu has appointed special extension personnel to deal with radicalism. This means that there are extension workers in the area of the Office of the Ministry of Religion of Palu City who have the expertise to guide and deal with issues related to radicalism. This was stated by 
one of the extension agents who said that the Office of the Ministry of Religious Affairs in Palu City had mapped and assigned extension workers who were specialized in dealing with issues related to radicalism. This means that the extension worker has the expertise to deal with the problem of radicalism, starting from the understanding and characteristics of radicalism that can lead to acts of terrorism. However, this does not mean that other extension agents are not given the opportunity to develop majelis taklim related to radicalism. Because we all have to fight against radicalism, which can lead to acts of terrorism.

This statement emphasizes the existence of a specific extension of the staff that is fully concentrated on the problems of radicalism. So, the majelis taklim congregation can get a comprehensive enlightenment on the problem of radicalism and at the same time have alternative solutions to overcome radicalism even though within the scope of their respective families.

\subsubsection{The positive response and enthusiasm of the majelis taklim congregation to radicalism}

Researchers saw the response and enthusiasm of the majelis taklim congregation in following coaching related to radicalism. They showed their seriousness in following the lectures given by religious extension workers. Even when the question and answer session was opened, almost all mothers gave responses, questions, and offered possible alternative solutions, at least in their neighborhood.

\subsubsection{MORA sends extension workers to attend professional improvement training}

Extension workers are always assigned by the Ministry of Religion to attend training. Assignments to take part in the training are intended to support and increase the professionalism of the extension personnel in carrying out their duties as an instructor. This was conveyed by one of the extension agents who said that to support and improves the skills of extension workers in carrying out their duties, the Office of the Ministry of Religion always assigns extension personnel to take part in professional improvement training.

\subsubsection{Cross-sector cooperation}

Another supporting factor is the existence of cross-sectoral cooperation carried out by the MORA of Palu to jointly fight radicalism. With this cross-sector cooperation, the guidance of majelis taklim is more comprehensive because radicalism is not only seen from the religious aspect, but is more comprehensive. This was stated by one of the extension agents who said that in carrying out the guidance of majelis taklim, especially those related to radicalism, we collaborated with several institutions that also paid attention to this radicalism, for example the Palu Regional Counter Terrorism National Agency and institutions including public figure. This cooperation has further strengthened the movement of the taklim assembly to overcome the dangers of radicalism.

The guidance of the majelis taklim congregation carried out by the MORA of Kota Palu is very good. This is due to several opportunities that greatly support the implementation of coaching. Therefore, these opportunities must continue to be nurtured, maintained, and continuously developed by the extension workers so that the synergy of fostering the majelis taklim congregation can run continuously. Especially recently, terrorism is a very terrible scourge and afflicts future generations. If taken to the root, one of the causes of terrorism is the existence of radicalism that is embedded in the children of this nation. This concept of radicalism continues to grow, which has sparked acts of terror.

Likewise, the involvement of social organizations such as Alkhairaat, Muhammadiyah, Nahdlatul Ulama (NU), Darul Dakwah wal Irsyad (DDI), As'adiyah, Dewan Dakwah Islam Indonesia (DDII), Persatuan Islam (Persis), Indonesia Berdzikir, and others, in learning majelis taklim, have the aim of preserving Islamic teachings. as rahmatan lil 'alamin (a gift to nature).

\subsection{The Iceberg Pattern of Anti-Radicalism Education in Kota Palu}

Radicalism in the name of religion that occurred in Kota Palu, for three consecutive years. The shooting of Reverend Susianti Tinulele in 2004, the Maesa Market bombing in 2005, and the shooting of Pastor Irianto Kongkoli in 2006. Incident after incident, which claimed lives, was an accumulation of disappointment and revenge by the perpetrators, against the Poso riots. A deadly event that worries the people of Kota Palu, because the iceberg theory shows an escalation of 
violence that only causes material and mental losses. As an applicable legal measure, the perpetrators were sentenced to terrorist crimes.

In connection with fears of escalating radicalization, Tito Karnavian argued that the problem of terrorism is like an iceberg, where if only the tip is cut, there are still bigger roots underneath. Terrorists are concerned with ideological issues. If it is embedded in someone's mind then it is difficult to beat it, even with weapons, shooting and arrest. Therefore, solving the terrorist problem requires the ability and concern of all parties, both the government and all levels of society. The trick is to counteract efforts to spread radicalism or ideology. In the family environment, you can always monitor the activities of their children. In addition, social media has a very important role in the spread of radicalism, especially the younger generation who easily access terrorist content [8].

Opportunities are faced with iceberg patterns, resulting in a harmonious approach between religious leaders, traditional leaders, community leaders, and the government so that radical cases can be resolved with legal decisions that are accepted by all parties. The foothills of the mountains were approached with warmth and strong social solidarity, so that the atmosphere of tension and mutual suspicion soon melted away and increased friendship between religious leaders, thus forming the Forum for Inter-Religious Harmony (Forum Kerukunan Antar Umat Beragama FKUB) at the level of Kota Palu, Provinsi Sulawesi Tengah, and all Kabupaten.

Due to the iceberg's melting pattern, some ice fragments still remain, which are very sharp and slippery. Likewise, educational activities in the Majelis Taklim Kota Palu still face several challenges and obstacles. The constraint referred to by the researcher in this case is anything that causes the lack of smoothness of the coaching process carried out by extension workers at the taklim assembly. In general, the researchers found several obstacles, including:

\subsubsection{The reluctance of mothers not to invite speakers because there are no funds to pay for the lecturers}

The factor of cash funds owned by majelis taklim is one of the obstacles. This is because if the majelis taklim's cash is in surplus, the recitation activities will run very smoothly. On the other hand, if the cash is lacking or even not available, the board management is reluctant to call and remind extension workers to come and provide guidance. Finally, cash conditions greatly affect the continuity of the majelis taklim coaching program because it "forces" the assemblies to tug-ofwar in presenting speakers.

\subsubsection{The extension workers do not know how to drive a motorized vehicle}

The facilities for official vehicles are actually owned by extension personnel which can be accessed by extension personnel to carry out activities. However, of the total number of extension workers, there are still some who are not able to drive the official vehicle, either two-wheeled vehicles or four-wheeled vehicles. The less skilled extension workers will be constrained by the fact that they have to use public transportation which is relatively long to arrive at their destination. Practically, the time allocation is more or less wasted due to the late arrival of the extension agents.

\subsubsection{Fund}

A common problem that is felt by almost all institutions and work units is the problem of lack of budget or fund allocations. This problem is also felt by some Islamic religious extension workers, especially those who are not civil servants. Meanwhile, the budget allocation to fulfill the entire mobilization of coaching activities carried out by Islamic religious extension workers in Kota Palu is not sufficient. Finally, all the extension workers were only determined to have no rattan, the roots became wrapped in a spirit of sincerity as Muslims who were called not only because of work, but because it was an obligation for everyone to preach.

Based on this explanation, it can be understood that behind the work ethic of the extension workers in fostering majelis taklim in Palu City, there are still several obstacles. Although these obstacles seem trivial and can still be overcome, they still need serious attention. This is due to a small obstacle even if it does not get good and intensive handling, it does not rule out that it will become a big obstacle. So, attention is needed so that all obstacles can be overcome by all parties. 


\section{Conclusion}

The several of discourse this paper, this is many conclusion :

7.1 Many potential of radicalism in Kota Palu, because the position at capital of Provinsi Sulawesi Tengah, each the Kabupaten Poso was the long conflict.

7.2. The MORA guidance in preventing radicalism in majelis taklim in Kota Palu applies several patterns and is used as a reference for all extension workers in providing guidance to majelis taklim.

7.3. Some of the guidance patterns are the establishment of a roadmap for the majelis taklim area, so that extension workers can easily respond to changes that occur.

\section{References}

[1] M. Jurgensmeyer, Terrorism in the Mind of God. Berkeley, CA: UC Press, 2003.

[2] A. Rodli, Stigma Islam Radikal. Jakarta: Pustaka Pelajar, 2013.

[3] D. R. Krathwohl, “A Revision of Bloom's Taxonomy: An Overview David," Theory Pract., vol. 41, no. 4, pp. 219-225, 2002.

[4] nasional.tempo, "Enam terduga Teroris Klaten dari satu Sekolah," nasional.tempo.co, no. September, 2018.

[5] P. Hekmatpour and T. J. Burns, "Radicalism and Enantiodromia : A Trialectic of Modernity, Postmodernity, and Radicalism and enantiodromia : A Trialectic of modernity, post-modernity, and anti-modernity in the Islamic World," no. May, 2020.

[6] S. Wiwitan, HARMONI; Dinamika penanganan gerakan keagamaan, vol. 11, no. September. 2012.

[7] G. S. Hassan, "Radical Islam / Islamic Radicalism : Towards a Theoretical Framing Radical Islam / Islamic Radicalism : Towards a Theoretical Framing,” no. September, 2014.

[8] Kumparan.com, "Terorisme Ibarat Gunung Es, Bawahnya Lebih Besar," Kumparan.com, 2018. 